\title{
THE EFFECT OF FINANCIAL INCLUSION AND FINANCIAL TECHNOLOGY ON EFFECTIVENESS OF THE INDONESIAN MONETARY POLICY
}

\author{
Birgitta Dian SARASWATI (1) ${ }^{*}$, Ghozali MASKI (102, David KALUGE® ${ }^{3 *}$, \\ Rachmad Kresna SAKTI 4 \\ ${ }^{1}$ Faculty of Economics and Business, Brawijaya University, Malang, Indonesia \\ ${ }^{1}$ Faculty of Economics and Business, Satya Wacana Christian University, Salatiga, Indonesia \\ 2, 3, ${ }^{4}$ Faculty of Economics and Business, Brawijaya University, Malang, Indonesia
}

Received 27 May 2019; accepted 18 November 2019

\begin{abstract}
The existence of non-inclusive households significantly reduces the effect of the interest rate change policy on households inter-temporal consumption decisions. Further, financial inclusion is closely related to fintech. On the one hand, fintech helps overcome the financial inclusion problem because fintech manages to reach those who were previously inaccessible by banks. On the other hand, fintech will change the payment system structure in an economy that will eventually affect the effectiveness of monetary policy. Using the Vector Error Correction Model (VECM) with the observation period of 2009-2018, this study aims to analyze the effects of financial inclusion and fintech on effectiveness of the Indonesian monetary policy within the framework of the transmission mechanism of monetary policy through interest rate channel with both the cost of capital effect and the substitution effect. The results demonstrate that financial inclusion level affects inflation rate as a proxy of effectiveness of the Indonesian monetary policy, both in the short run and long run. However, the effect of shocks in financial inclusion on inflation is not permanent. Meanwhile, fintech only affects inflation rate in the short run. However, shocks in fintech affect the volatility of inflation rate is permanent both through the substitution effect and the cost of capital effect.
\end{abstract}

Keywords: financial inclusion, financial technology (Fintech), inflation, transmission mechanism of monetary policy, interest rate channel, Vector Error Correction Model (VECM).

JEL Classification: E52.

\section{Introduction}

Financial inclusion has been recently an important topic in several international economic discussion forums because many consider it to be an effective solution to eradicate poverty problem that is common in many countries worldwide. Countries propose various policies to enhance financial inclusion among their population. In Indonesia, the government through Financial Service Authority (Otoritas Jasa Keuangan - OJK) in 2015 launched the officeless financial service program (Laku Pandai - Layanan Keuangan Tanpa Kantor) to encourage financial inclusion. This program focuses on remote areas that make it difficult for formal financial institutions to access. It is expected that this program manages to elevate the prosperity of the population in those areas who are mostly below the poverty line. Eventually, financial inclusion aims to increase public welfare through sustainable economic growth. Oji (2015) and Zulfiqar, Chaudary, and Aslam (2016) conclude that financial inclusion is the foundation and necessary condition of sustainable and inclusive economic growth. Several other studies support this conclusion by demonstrating that financial inclusion has a positive effect on economic growth (Sahay et al., 2015; Dabla et al., 2015; Onaolapo, 2015; Julie, 2013). In several Asian countries have a relatively low access to formal financial institutions. Specifically, in 2014 only 69 percent (36.1 percent) of the total adult population in East Asia and Pacific (Indonesia) who have accounts at formal financial institutions. It is then likely that this condition affects the transaction behavior of population and eventually their responses to governments' various economic policies, especially monetary ones (Worldbank, 2014).

*Corresponding author. E-mail: birgitta.saraswati@staff.uksw.edu 
In analyzing the effect of financial inclusion on the effectiveness of monetary policies, it is worth considering that a portion of the population has access to formal financial institutions while others do not. Those who do not have access to formal financial institutions are arguably not directly affected by interest rate policies, thus making those monetary policies less effective (Gali, Salido, \& Valles, 2004). Greater financial inclusion implies greater interest elasticity that eventually enhances the effectiveness of monetary policies. Mbutor (2013) support this argument by showing that financial inclusion positively affects the effectiveness of the Nigerian monetary policies. Mehrota and Yetman (2014) also lends a support to Mbutor (2013) by indicating that optimal monetary policy is sensitive to financial inclusion level in 130 countries. Countries with higher financial inclusion exhibit more effective monetary policies.

Nevertheless, financial inclusion can also negatively affect the effectiveness of monetary policy. The efficacy of monetary policy largely depends on the banking condition. When the banking condition worsens, public trust in banks will decline and the intermediary function of banks will deteriorate that will eventually lead to ineffective monetary policy. Khan (2011) shows that financial inclusion level is likely to increase banking credit risk because of banks' efforts to reach the unbankable population in their credit channeling that attenuate the effectiveness of monetary policy. In a similar vein, Dupas et al. (2013) finds that financial inclusion in Kenya is not associated with increased public trust in their banks. Consequently, Kenya exhibits ineffective monetary policy. Lenka and Bairwa (2016) also find similar results in their SAARC countries setting.

However, several studies argue that financial inclusion as a proxy for the proportion of the population with access to formal financial institutions affects the effectiveness of monetary policy. For example, Ascari, Colciago, and Rossi (2011) demonstrate the insignificant role of participation in the market of financial assets in the framework of the effectiveness of monetary policy. The study implies that limited financial inclusion does not affect the effectiveness of monetary policy. Lapukeni (2015) and Evans (2016) support Ascari et al. (2011) by indicating that the level of financial inclusion does not affect the effectiveness of monetary policy in Malawi and Africa. Even in Africa, the effectiveness of monetary policy affects financial inclusion and not vice versa.

Analyzing the effect of financial inclusion on the effectiveness of monetary policy is closely related to the development of financial technology (fintech). Fintech facilitates greater access to financial services that will increase the level of financial inclusion. Thus, it can be argued that the level of financial inclusion depends on fintech development (Nakaso, 2016; Alexander, 2017). Fintech encompasses various financial service activities, such as payment, transfer, stock trading, peer-to-peer lending and many more. Nevertheless, the payment sector dominates fintech, especially in ASEAN countries (Sicilia, 2017).
Similarly, the payment sector dominates fintech in Indonesia. According to OJK, until 2018, fintech in the payment sector contributes to $42.22 \%$ of total fintech. The lending sector follows by contributing to $17.78 \%$ of total fintech while other sectors such as crowdfunding, financial planning contribute the rest (Kontan, 2018).

The development of fintech will arguably change the structure of the payment system in the economy. Further, the changing structure of the payment system implies changes in the financial behavior of the population and eventually affects the financial stability and monetary policy. However, the effect of fintech on monetary policy is still an open empirical question. Mylonas, Schich, and Wehinger (2000) suggests that fintech as the latest development of financial markets affects the effectiveness of monetary policy. Fintech causes the prices of financial assets are more sensitive to interest rate changes that will strengthen the effect of monetary policy on an economy. Mishra and Pradhan (2008) confirm Mylonas et al. (2000) by indicating that fintech as a financial innovation will strengthen the role of the interest rate as a transmission mechanism of monetary policy. However, Mishra and Pradhan (2008) argue that in the continuously developing financial markets, the rapid advance of financial technology will only increase the effectiveness of monetary policy in the short run. Findings that differ from previous findings reveald by Salomon and Klause-Jurgen (2017) where fintech as a financial innovation does not affect monetary policy.

This study aims to investigate the effects of financial inclusion and fintech on the effectiveness of monetary policies for several reasons. Firstly, studies that investigate the effects of financial inclusion and fintech on the effectiveness of monetary policy show conflicting results. Secondly, several countries, especially developing and less developed ones, still exhibit a significant percentage of the adult population with no access to formal financial institutions. Thirdly, fintech plays an increasingly important role in the economy due to its rapid development. Specifically, the research questions of this study is How the effects of financial inclusion and fintech on inflation as the final objective of monetary policy within the framework of the transmission mechanism of interest-based monetary policy either through cost-of-capital or substitution effects.

The paper is structured as follows: we review the subject literature and provide some background and context for researches done until now. VECM methodolgy was discussed, and the framework for using information from Indonesia economy and applying the model was lay out in this study. We then concludes the paper.

\section{Literature review}

\subsection{Theoretical review}

There are various definitions of financial inclusion in the literature. For example, Bank Indonesia (2014) defines financial inclusion as all efforts to enhance public access 
to financial services by eliminating all price and nonprice constraints. Besides, according to IMF in Zulfiqar, Chaudhary, and Aslam (2016) financial inclusion refers to the availability of financial services for all population, especially the poor ones. Further, Khan (2011) defines financial inclusion as guaranteed access to financial services with affordable costs for the low-income population. Lastly, Julie (2013) defines financial inclusion as a condition where everyone can access financial services and products they want so that they can manage their financial matters well.

In a similar vein, there are various definitions of fintech. For example, Svetlana and Irina (2017) defines fintech as firms that use modern technology in financial systems. Meanwhile, Merit Authorities of Financial Stability Boards (FBS) defines fintech as a technological innovation in financial services.

Further, Bank Indonesia defines fintech as the use of technology in a financial system that offers novel products, services, technology, and/or business models and potentially affects the stability of the monetary and financial systems and/ or the efficiency, continuity, security, and reliability of the payment system.

In explaining the effect of financial inclusion on the country's welfare in the monetary policy framework, we refer to Mehrota and Yetman (2014) who proposes a model based on household and firm behavior. In the model, there are two types of households, namely households with access to the financial market (inclusive households) and households without access to financial markets (noninclusive). From the firm perspective, it is assumed that firms use the Cobb-Douglas production technique in their production decisions.

$$
X_{j, t}=A_{t} K_{j, t-1}^{\alpha} N_{j, t}^{1-\alpha},
$$

where $A$ is the productivity level. The above productive function suggests that variable $N$ refers to total labor provided by both inclusive and non-inclusive households. Consequently, this production function indicates that financial inclusion affects the outputs of an economy. Eventually, financial inclusion will affect inflation rate.

The role of fintech in facilitating price or inflation stabilization objective in the framework of monetary policy lies in the effect of fintech on the equilibrium in financial and goods markets. In goods markets, the development of fintech enlarges the access to financial markets that will enhance financial inclusiveness and investments by business actors (Mishra \& Pradhan, 2008). The development of fintech leads to more diverse financing sources and less reliance on bank-based financing source. Eventually, more diverse financing sources will arguably increase investments and shift the equilibrium in goods markets.

Meanwhile, in financial markets, fintech affects the equilibrium condition by affecting money supply and demand. Fintech, including various financial innovation, will affect money supply and demand (Mishra \& Pradhan, 2008). Further, fintech will generate novel instruments in financial markets that will serve as the transaction tools that will affect money demand. On the money supply side, fintech will affect money multiplier. The fintech development will reduce the preference to hold cash money that will affect the ratio between cash money and deposit and eventually money multiplier. In this respect, fintech affects outstanding money by increasing money multiplier.

By affecting the equilibrium in goods and financial markets, fintech will automatically affect aggregate demands in the economy because aggregate demands are derived from goods and financial market equilibrium. Besides affecting aggregate demands, fintech will also affect aggregate supply in the economy. As mentioned before, the fintech development enables firms as economic actors that produce goods and services to acquire financing sources in their production processes. More easily accessible financing sources will increase firms' investments and eventually their outputs. Overall, the fintech development affects aggregate demands and supply in the economy and eventually general price index in the economy (inflation).

\subsection{Previous studies}

\subsubsection{The relationship between financial inclusion and the effectiveness of monetary policy}

Several studies have investigated the relationship between financial inclusion and the effectiveness of monetary policy. For example, Mbutor (2013) analyzes the effect of financial inclusion on monetary policy in Nigeria by considering the role of financial inclusion in transmitting monetary policy. The study uses the following indicators as the proxies of the financial inclusion variable: the number of bank branch offices, the ratio between outstanding loan and GDP, and the amount of deposit loan in rural bank branch offices. Meanwhile, inflation rate is the proxy of the monetary policy variable. This study demonstrates that the number of bank branch offices negatively affects the effectiveness of monetary policy, probably because a greater number of bank branch offices still serve only a relatively limited number of consumers. It is likely that the opening of new bank branch offices mainly aims to generate profits and not to enhance financial inclusion, leaving some branch offices not fully utilized. However, other indicators of financial inclusion positively affect the effectiveness of monetary policy. Further, Mehrota and Yetman (2014) investigate the effect of financial inclusion on monetary policy in 130 countries worldwide. Using the Vector Autoregression approach and classifying countries into two groups (countries with a high level of financial inclusion and those with a low level of financial inclusion), this study shows that 1 ). financial inclusion affects inflation and output volatility 2). for countries with a high level of financial inclusion, productivity shock leads to lower output and inflation volatility and 3 ). The optimal monetary policy is sensitive to the level of financial inclusion. Evans (2016) demonstrates slightly different results from previously mentioned studies. Using 15 African countries 
for observation years of 2005-2014, this study empirically indicates that the level of financial inclusion affects the effectiveness of monetary policy only in the short run. In the long run, the effectiveness of monetary policy mainly depends on interest rate. Evans (2016) mainly differs from previous studies by showing that the effectiveness of monetary policy affects the level of financial inclusion and not vice versa.

Meanwhile, Khan (2011) demonstrates the negative impact of financial inclusion on the effectiveness of monetary policy. This study suggests that financial inclusion is likely to increase bank credit risk because banks aim to reach the unbankable population in their credit channeling decision. Similarly, using Kenyan context, Dupas et al. (2013) shows that financial inclusion is not associated with increased public trust in banks, thus leading to the suboptimal function of banks.

Several other studies even demonstrate that financial inclusion has no effect on monetary policy (Ascari et al., 2011). Lapukeni (2015) lends a support to Ascari et al. (2011) by indicating that M2 money supply and exchange rate significantly affect the effectiveness of monetary policy in Malawi while financial inclusion has no impact on the effectiveness of financial policy probably because the economy of Malawi largely depends on import. Besides, Evans' study in Africa (2016) also shows similar results to Ascari et al. (2011) and Lapukeni (2015) by indicating that financial inclusion has no effect on the effectiveness of monetary policy. This study even suggests a one-way causal relationship between financial inclusion and the effectiveness of monetary policy where even the effectiveness of monetary policy affects the level of financial inclusion.

Financial inclusion is likely to not only affect the effectiveness of monetary policy but also financial stability. Using the General Method of Moment method to analyze the effect of financial inclusion on financial stability (measured by Bank z score) in Sub Saharan countries, Amatus (2015) demonstrates that financial inclusion enhances financial stability. Using the same method in Asian countries, Dienillah, Azka, and Anffraeni (2016) shows that financial inclusion affects financial stability as measured by bank $\mathrm{z}$ score. However, the effect is moderate. These studies arguably confirm previous studies of Hannig and Jansen (2010) who indicate that financial inclusion positively affects financial stability.

\subsubsection{The relationship between financial inclusion and Fintech}

In analyzing the relationship between financial inclusion and fintech, Nakaso (2016) explains that the relationship between financial inclusion and fintech is based on the fact that fintech enhances financial inclusion. Fintech facilitates ones to access financial services more easily. In a similar vein, Alexander (2017) argues that fintech potentially increases financial inclusion by enhancing access to financial services of individuals and firms that previously had no access to formal financial institutions. Fintech firms have developed digital financial services that enable million people to access the banking sector, albeit geographical obstacles and lack of infrastructure in financial markets that constrain the coverage of financial services, especially in developing countries.

\subsubsection{The relationship between Fintech and monetary policy}

The relationship between fintech and monetary policy is still an empirical question. Mylonas et al. (2000) hold that fintech as a form of the development of financial market significantly affects the effectiveness of monetary policy. Fintech causes financial asset prices to be more sensitive to interest rate changes that implies that fintech affects monetary policy through its effects on interest rate and eventually on financial asset prices. Mishra and Pradhan (2008) confirms Mylonas et al. (2000) by showing that fintech as a form of financial innovation strengthens the role of interest rate in transmitting monetary policy. Besides, Hawkins (2001) and Al-Laham, Al-Tarawneh, and Abdalat (2009) demonstrate that e-money as the development of fintech will affect the effectiveness of monetary policy through its effect on the velocity of money. However, they further argue that continuously developing financial market condition and more advanced financial technology will only cause monetary policy to be more effective in the short run. Different from Mylonas et al. (2000) and Mishra and Pradhan (2008), Fiedler et al. (2017) conclude that fintech as a form of financial innovation does not directly affect monetary policy. Fintech will only directly affect monetary policy if conventional currency competes against digital money issued by non-banking firms. Digital money limits the ability of policymakers in maneuvering in their monetary policy. However, at the same time, competition from digital money reduces the possibility of abuse in the case of money supply monopolized by central banks.

\section{Research methodology}

\subsection{Data type and source}

This study uses time-series data with the observation period of between 2009.Q1-2018.Q1. specifically, we use the following data for our analysis: inflation rate, the interest rate of the inter-bank money market, lending interest rate, deposit interest rate, the amount of E-Money, the level of $\mathrm{M}_{2}$ money supply, gross domestic product, and the financial inclusion indicator. We collect the data from the Indonesian financial and economy statistic (SEKI - Statistik Ekonomi dan Keuangan Indonesia), the Indonesian Financial System Statistic (SSKI - Statistika Sistem Keuangan Indonesia) (Bank Indonesia, 2018) and International Financial Statistic (IFS).

This study measures the effectiveness of monetary policy by the effects of fintech and financial inclusion on the inflation rate as the sole objective of the Indonesian monetary policy. Further, The following is the formula to 
measure the level of financial inclusion (Index of Financial Inclusion) that refers to Sarma (2012):

$$
\begin{aligned}
& I F I=\frac{1}{2}\left[\frac{\sqrt{d_{1}^{2}+d_{2}^{2}+\ldots+d_{n}^{2}}}{\sqrt{n}}+\right. \\
& \left.\left(1-\frac{\sqrt{\left(1-d_{1}\right)^{2}+\left(1-d_{2}\right)^{2}+\ldots+\left(1-d_{n}\right)^{2}}}{\sqrt{n}}\right)\right],
\end{aligned}
$$

where: $n$ : the number of dimensions; IFI: Index of Financial Inclusion.

To measure Index of Financial Inclusion, this study uses the following four information that represent banking penetration, the availability of banking services, and usage: the number of deposit accounts per 1000 adult population (a proxy of the banking penetration dimension), the number of bank branch offices and ATMs per 100,000 adult population that represents the availability of banking services dimension), and the ratio between total deposit and credit and total GDP to represent the usage dimension. We use the ratio between electronic money and total money supply in the broad term $\left(\mathrm{M}_{2}\right)$.

\subsection{Analysis method}

To answer the research questions, this study relies on the Vector Error Correction Model (VECM) analysis method. This model is a restricted form of the vector autoregression (VAR) model because the data in the VECM model is not stationary at level. This model offers more advantage than the VAR model because it can identify the long-run relationship and identify the duration of shock (transitory or permanent). We use the VECM model in this study because different from SVAR, this model enables us to separate the long-run and the short-run components in investigating the effects of financial inclusion and fintech on inflation as the final target of the Indonesian monetary policy. Besides, by using the impulse response as our analytical tool, we could predict the present and future values of the inflation rate due to shocks. Greene (2002) defines impulse response as a channel where variables will return to their equilibrium position after experiencing shocks.

\subsection{Model specification}

The VECM model is a restricted vector autoregression (VAR) model because the data is not stationary at the level but at the first difference. However, there is a cointegrated relationship between variables in the system (Pfaff \& Im Taunus, 2008).

In general, the following is the VAR model with $\mathrm{K}$ endogenous variables:

$$
\begin{aligned}
& y_{t}=\left(y_{1 t}, \ldots, y_{k t}, \ldots, y_{K t}\right), \text { for } k=1, \ldots, k ; \\
& y_{t}=A_{1} y_{t-1}+\ldots+A_{p} y_{t-p}+u_{t},
\end{aligned}
$$

where $A_{i}$ is $(K \times K)$ matrix coefficient for $i=1, \ldots, p$ and $\mu_{t}$ is $K$ dimension with $E\left(u_{t}\right)=0$, and matrix $E\left(u_{t} u_{t}\right)=\sum u$ (white noise).

An important characteristic of the VAR model is that all endogenous variables in the model are stationary or stable. Consequently, we run a test to investigate whether the variables are stationary by performing the polynomial evaluation.

$$
\operatorname{det}\left(I_{K}-A_{1 z}-\ldots-A_{p} z^{p}\right) \neq 0 \text { for }|z| \leq 1
$$

If a variable has a unit root, then $z=1$ and it indicates that the variable is not stationary at level and first difference $I(1)$ is necessary. However, when cointegration between variables exists, the Vector Error Correction Model (VECM) is plausible for the analysis. Because VECM is a first difference form, the following is the VECM formula:

$$
\Delta y_{t}=\alpha \beta y_{t-p}+\Gamma_{1} \Delta y_{t-1}+\ldots+\Gamma_{p-1} y_{t-p+1}+u_{t}
$$

with

$$
\Gamma_{i}=-\left(I-A_{1}-\ldots-A_{i}\right), \quad i=1,2, \ldots, p-1
$$

and

$$
\pi=\alpha \beta^{T}=-\left(I-A_{i}-\ldots-A_{p}\right) .
$$

Matrix $\pi=\alpha \beta^{T}$ is reduced rank, while $\alpha$ and $\beta$ dimensions are $K \times r$ and $r$ is the cointegration level. For example, to analyze the number of $y_{t}$ variables with longrun relationship, $\alpha$ indicates loading matrix while $\beta$ is the long-run relationship.

To analyze the effects of fintech and the level of financial inclusion on the effectiveness of the Indonesian monetary policy, this study uses two VECM estimation models:

1. The interest rate model through its the cost of capital effect.

This model estimates the effects of financial inclusion and fintech on inflation as the proxy of the effectiveness of monetary policy by underscoring the monetary policy transmission mechanism through the interest rate channel with cost of capital.

$$
\text { Inf }=\mathrm{f}(\text { PUAB, Loan, Fint, FI, Inv, OutGap), }
$$

where:

Inf: inflation rate as the final target of the monetary policy.

PUAB: JIBOR inter-bank money market interest rate

Loan: loan interest rate

Fint: the ratio between e-money and outstanding money as the proxy of financial technology

FI: $\quad$ Financial Inclusion Index

Inv: Investment Expenditure

OutGap: Output Gap

In this respect, there are seven variables that will be estimated by the VECM model. The specification arguably leads to a more complex analysis because it has more possibilities of the number of linear combinations between these seven variables (whether these combinations are stationary at level 0,1 , or 2 ). The absence of the 
cointegrated relationship between these seven variables indicates that there is no long-term relationship between these variables, thus implying that there will be no ECT in the seven formed equations. However, if there is at least one cointegrating relationship between these seven variables, the long-term relationship will apply to all variables in the specification. Thus, the following formulas specify the VECM model:

$$
\begin{aligned}
& \Delta I n f_{t}=\alpha_{1}+\sum_{i=1}^{n} \beta_{11} \Delta I n f_{t-i}+\sum_{i=1}^{n} \beta_{12} \Delta P U A B_{t-i}+ \\
& \sum_{i=1}^{n} \beta_{13} \Delta \operatorname{Loan}_{t-i}+\sum_{i=1}^{n} \beta_{14} \Delta F \text { int }_{t-i}+\sum_{i=1}^{n} \beta_{15} \Delta F I_{t-i}+ \\
& \sum_{i=1}^{n} \beta_{16} \Delta \operatorname{Inv} v_{t-i}+\sum_{i=1}^{n} \beta_{17} \Delta \text { OutGap }_{t-i}+\lambda_{1} E C T_{t-1}^{\text {Inf }}+\mu_{I N F t}
\end{aligned}
$$

$$
\begin{aligned}
& \Delta P U A B_{t}=\alpha_{2}+\sum_{i=1}^{n} \beta_{21} \Delta P U A B_{t-i}+\sum_{i=1}^{n} \beta_{22} \Delta I n f_{t-i}+ \\
& \sum_{i=1}^{n} \beta_{23} \Delta \text { Loan }_{t-i}+\sum_{i=1}^{n} \beta_{24} \Delta \text { Fint }_{t-i}+\sum_{i=1}^{n} \beta_{25} \Delta F I_{t-i}+ \\
& \sum_{i=1}^{n} \beta_{26} \Delta \operatorname{Inv} v_{t-i}+\sum_{i=1}^{n} \beta_{27} \Delta \text { OutGap }_{t-i}+\lambda_{2} E C T_{t-1}^{P U A B}+\mu_{P U A B t}
\end{aligned}
$$

$$
\begin{aligned}
& \Delta \text { Loan }_{t}=\alpha_{3}+\sum_{i=1}^{n} \beta_{31} \Delta \operatorname{Loan}_{t-i}+\sum_{i=1}^{n} \beta_{32} \Delta \operatorname{Inf}_{t-i}+ \\
& \sum_{i=1}^{n} \beta_{33} \Delta P U A B_{t-i}+\sum_{i=1}^{n} \beta_{34} \Delta F \text { int }_{t-i}+\sum_{i=1}^{n} \beta_{35} \Delta F I_{t-i}+ \\
& \sum_{i=1}^{n} \beta_{36} \Delta \operatorname{Inv} v_{t-i}+\sum_{i=1}^{n} \beta_{37} \Delta \text { OutGap }_{t-i}+\lambda_{3} E C T_{t-1}^{\text {Loan }}+\mu_{\text {Loant }}
\end{aligned}
$$

$$
\begin{aligned}
& \Delta F \text { int }_{t}=\alpha_{4}+\sum_{i=1}^{n} \beta_{41} \Delta F \text { int }_{t-i}+\sum_{i=1}^{n} \beta_{42} \Delta \operatorname{Inf}_{t-i}+ \\
& \sum_{i=1}^{n} \beta_{43} \Delta P U A B_{t-i}+\sum_{i=1}^{n} \beta_{44} \Delta \operatorname{Loan}_{t-i}+\sum_{i=1}^{n} \beta_{45} \Delta F I_{t-i}+ \\
& \sum_{i=1}^{n} \beta_{46} \Delta I n v_{t-i}+\sum_{i=1}^{n} \beta_{47} \Delta O u t G a p_{t-i}+\lambda_{4} E C T_{t-1}^{F \text { int }}+\mu_{F \text { int } t}
\end{aligned}
$$

$$
\begin{aligned}
& \Delta F I_{t}=\alpha_{5}+\sum_{i=1}^{n} \beta_{51} \Delta F I_{t-i}+\sum_{i=1}^{n} \beta_{52} \Delta \operatorname{Inf}_{t-i}+ \\
& \sum_{i=1}^{n} \beta_{53} \Delta P U A B_{t-i}+\sum_{i=1}^{n} \beta_{54} \Delta \operatorname{Loan}_{t-i}+\sum_{i=1}^{n} \beta_{55} \Delta F \text { int }_{t-i}+ \\
& \sum_{i=1}^{n} \beta_{56} \Delta \operatorname{Inv} v_{t-i}+\sum_{i=1}^{n} \beta_{57} \Delta \text { OutGap }_{t-i}+\lambda_{5} E C T_{t-1}^{F I}+\mu_{F I t}
\end{aligned}
$$

$\Delta I n v_{t}=\alpha_{6}+\sum_{i=1}^{n} \beta_{61} \Delta I n v_{t-i}+\sum_{i=1}^{n} \beta_{62} \Delta I n f_{t-i}+$

$\sum_{i=1}^{n} \beta_{63} \Delta P U A B_{t-i}+\sum_{i=1}^{n} \beta_{64} \Delta \operatorname{Loan}_{t-i}+\sum_{i=1}^{n} \beta_{65} \Delta F$ int $_{t-i}+$

$\sum_{i=1}^{n} \beta_{66} \Delta F I_{t-i}+\sum_{i=1}^{n} \beta_{67} \Delta O u t G a p_{t-i}+\lambda_{6} E C T_{t-1}^{\text {Inv }}+\mu_{\text {Invt }} ;$

$\Delta$ OutGap $_{t}=\alpha_{7}+\sum_{i=1}^{n} \beta_{71} \Delta$ OutGap $p_{t-i}+\sum_{i=1}^{n} \beta_{72} \Delta \operatorname{Inf} f_{t-i}+$

$\sum_{i=1}^{n} \beta_{73} \Delta P U A B_{t-i}+\sum_{i=1}^{n} \beta_{74} \Delta$ Loan $_{t-i}+\sum_{i=1}^{n} \beta_{75} \Delta F$ int $_{t-i}+$

$\sum_{i=1}^{n} \beta_{76} \Delta F I_{t-i}+\sum_{i=1}^{n} \beta_{77} \Delta I n v_{t-i}+\lambda_{7} E C T_{t-1}^{\text {Outgap }}+\mu_{\text {OutGapt }}$.

2. The interest rate model through the substitution effect

This model estimates the effect of financial inclusion and fintech on inflation as the proxy of the effectiveness of the monetary policy through the monetary policy transmission mechanism with the substitution effect.

$$
\text { Inf }=\mathrm{f}(\mathrm{PUAB} \text {, Deprate, Fint, FI, Cons, OutGap) }
$$

The following formulas estimate the VECM model.

$$
\begin{aligned}
& \Delta \operatorname{Inf}_{t}=\theta_{1}+\sum_{i=1}^{n} \gamma_{11} \Delta \operatorname{Inf_{t-i}}+\sum_{i=1}^{n} \gamma_{12} \Delta \text { PUAB }_{t-i}+ \\
& \sum_{i=1}^{n} \gamma_{13} \Delta \text { Deprate }_{t-i}+\sum_{i=1}^{n} \gamma_{14} \Delta F \text { int }_{t-i}+\sum_{i=1}^{n} \gamma_{15} \Delta F I_{t-i}+ \\
& \sum_{i=1}^{n} \gamma_{16} \Delta \text { Cons }_{t-i}+\sum_{i=1}^{n} \gamma_{17} \Delta \text { OutGap }_{t-i}+\delta_{1} E C T_{t-1}^{\text {Inf }}+\varepsilon_{\text {Inft }}
\end{aligned}
$$

$$
\begin{aligned}
& \Delta \text { PUAB }_{t}=\theta_{2}+\sum_{i=1}^{n} \gamma_{21} \Delta \text { PUAB }_{t-i}+\sum_{i=1}^{n} \gamma_{22} \Delta \operatorname{Inf}_{t-i}+ \\
& \sum_{i=1}^{n} \gamma_{23} \Delta \text { Deprate }_{t-i}+\sum_{i=1}^{n} \gamma_{24} \Delta F \text { int }_{t-i}+\sum_{i=1}^{n} \gamma_{25} \Delta F I_{t-i}+ \\
& \sum_{i=1}^{n} \gamma_{26} \Delta \text { Cons }_{t-i}+\sum_{i=1}^{n} \gamma_{27} \Delta \text { OutGap }_{t-i}+\delta_{2} E C T_{t-1}^{P U A B}+\varepsilon_{P U A B t}
\end{aligned}
$$

$$
\begin{aligned}
& \Delta \text { Deprate }_{t}=\theta_{3}+\sum_{i=1}^{n} \gamma_{31} \Delta \text { Deprate }_{t-i}+\sum_{i=1}^{n} \gamma_{32} \Delta I n f_{t-i}+ \\
& \sum_{i=1}^{n} \gamma_{33} \Delta \text { PUAB }_{t-i}+\sum_{i=1}^{n} \gamma_{34} \Delta F \text { int }_{t-i}+\sum_{i=1}^{n} \gamma_{35} \Delta F I_{t-i}+ \\
& \sum_{i=1}^{n} \gamma_{36} \Delta \text { Cons }_{t-i}+\sum_{i=1}^{n} \gamma_{37} \Delta \text { OutGap }_{t-i}+\delta_{3} E C T_{t-1}^{\text {Deprate }}+\varepsilon_{\text {Depratet }}
\end{aligned}
$$


$\Delta F$ int $_{t}=\theta_{4}+\sum_{i=1}^{n} \gamma_{41} \Delta F$ int $_{t-i}+\sum_{i=1}^{n} \gamma_{42} \Delta \operatorname{Inf} f_{t-i}+$

$\sum_{i=1}^{n} \gamma_{43} \Delta P U A B_{t-i}+\sum_{i=1}^{n} \gamma_{44} \Delta$ Deprate $_{t-i}+\sum_{i=1}^{n} \gamma_{45} \Delta F I_{t-i}+$

$\sum_{i=1}^{n} \gamma_{46} \Delta$ Cons $_{t-i}+\sum_{i=1}^{n} \gamma_{47} \Delta$ OutGap $p_{t-i}+\delta_{4} E C T_{t-1}^{F i n t}+\varepsilon_{F i n t}$

$\Delta F I_{t}=\theta_{5}+\sum_{i=1}^{n} \gamma_{51} \Delta F I_{t-i}+\sum_{i=1}^{n} \gamma_{52} \Delta I n f_{t-i}+$

$\sum_{i=1}^{n} \gamma_{53} \Delta P U A B_{t-i}+\sum_{i=1}^{n} \gamma_{54} \Delta$ Deprate $_{t-i}+\sum_{i=1}^{n} \gamma_{55} \Delta F$ int $_{t-i}+$

$\sum_{i=1}^{n} \gamma_{56} \Delta$ Cons $_{t-i}+\sum_{i=1}^{n} \gamma_{57} \Delta$ OutGapt-i $+\delta_{5} E C T_{t-1}^{F I}+\varepsilon_{F I t} ;$

$\Delta$ Cons $_{t}=\theta_{6}+\sum_{i=1}^{n} \gamma_{61} \Delta$ Cons $_{t-i}+\sum_{i=1}^{n} \gamma_{62} \Delta \operatorname{Inf}_{t-i}+$

$\sum_{i=1}^{n} \gamma_{63} \Delta P U A B_{t-i}+\sum_{i=1}^{n} \gamma_{64} \Delta$ Deprate $_{t-i}+\sum_{i=1}^{n} \gamma_{65} \Delta F$ int $_{t-i}+$

$\sum_{i=1}^{n} \gamma_{66} \Delta F I_{t-i}+\sum_{i=1}^{n} \gamma_{67} \Delta O u t G a p_{t-i}+\delta_{6} E C T_{t-1}^{\text {Cons }}+\varepsilon_{\text {Const }}$

$$
\begin{aligned}
& \Delta \text { OutGap }_{t}=\theta_{7}+\sum_{i=1}^{n} \gamma_{71} \Delta \text { OutGap }_{t-i}+\sum_{i=1}^{n} \gamma_{72} \Delta \operatorname{Inf}_{t-i}+ \\
& \sum_{i=1}^{n} \gamma_{73} \Delta P U A B_{t-i}+\sum_{i=1}^{n} \gamma_{74} \Delta \text { Deprate }_{t-i}+\sum_{i=1}^{n} \gamma_{75} \Delta F \text { int }_{t-i}+ \\
& \sum_{i=1}^{n} \gamma_{76} \Delta F I_{t-i}+\sum_{i=1}^{n} \gamma_{77} \Delta \text { Cons }_{t-i}+\delta E C T_{t-1}^{\text {Outgap }}+\varepsilon_{\text {OutGapt }},
\end{aligned}
$$

where:

Inf: inflation rate as the final target of the monetary policy.

PUAB: JIBOR inter-bank money market interest rate

Loan: loan interest rate

Fint: the ratio between e-money and outstanding money as the proxy of financial technology

FI: $\quad$ Financial Inclusion Index

Inv: Investment Expenditure

Konst: Consumption Expenditure

OutGap: Output Gap

$E C T_{t}: \quad$ Error Correction Term

\section{Results and discussion}

Before estimating the VECM model, we run the stationary test to avoid spurious regression. We run unit root test according to the deterministic form contained in each variable from the Augmented Dickey-Fuller (ADF) indicator (Table 1).

Unit root test indicates that not all variables are sta-

\begin{tabular}{|c|c|c|c|c|}
\hline Variable & URT & $\begin{array}{c}\text { Mac-Kinnon Critical } \\
\text { Value }(5 \%)\end{array}$ & ADF Value & Explanation \\
\hline Inf & Level & -2.945842 & -4.743015 & Stationary \\
\hline \multirow{2}{*}{ PUAB } & Level & -2.948404 & -2.105177 & Not stationary \\
\hline & First Difference & -2.948404 & -4.651791 & Stationary \\
\hline \multirow{2}{*}{ Loan } & Level & -2.948404 & -1.585744 & Not stationary \\
\hline & First Difference & -2.612874 & -2.799746 & Stationary \\
\hline \multirow{2}{*}{ Deprate } & Level & -2.951125 & -2.643343 & Not stationary \\
\hline & First Difference & -2.614300 & -2.746438 & Stationary \\
\hline \multirow{2}{*}{ Fint } & Level & -2.945842 & 1.685642 & Not stationary \\
\hline & First Difference & -2.948404 & -4.570295 & Stationary \\
\hline \multirow{2}{*}{ FI } & Level & -2.945842 & -0.876452 & Not stationary \\
\hline & First Difference & -2.948404 & -5.958269 & Stationary \\
\hline \multirow{2}{*}{ Inv } & Level & -2.945842 & -1.129948 & Not stationary \\
\hline & First Difference & -2.948404 & -5.634281 & Stationary \\
\hline \multirow{2}{*}{ Cons } & Level & -2.945842 & -1.078994 & Not stationary \\
\hline & First Difference & -2.948404 & -5.955071 & Stationary \\
\hline OutGap & Level & -2.967767 & -8.741350 & Stationary \\
\hline
\end{tabular}
tionary at level. However, at the first difference degree,

Table 1. Stationarity Testing Using Augmented Dickey-Fuller (ADF) indicator 
all variables are stationary. However, the Johansen test indicates the cointegration between variables that implies long-term equilibrium both in the interest rate through the cost of capital effect and in the interest rate model through the substitution effect (Tables 2 and 3 ). This study uses the lag length of one in both models based on the results of the optimal lag length test (Table 4).

After determining the optimal lag length, we then estimate the VECM model. The following are the estimation results of the effect of fintech and financial inclusion on the effectiveness of monetary policy as reflected by the inflation rate in Indonesia within the framework of the transmission mechanism of monetary policy through interest rate channel with both the cost of capital effect and the substitution effect.

\subsection{The transmission mechanism of monetary policy through interest rate channel with the substitution effect}

The estimation results, through the substitution effect, demonstrate that financial inclusion level exhibits significantly negative short-term and long-term effects on the
Table 4. The Lag Length Test using the LR and SC tests

\begin{tabular}{|c|c|c|c|c|}
\hline \multirow{2}{*}{ Lag } & \multicolumn{2}{|c|}{ LR } & \multicolumn{2}{c|}{ SC } \\
\cline { 2 - 5 } & $\begin{array}{c}\text { The Cost } \\
\text { of Capital } \\
\text { Effect }\end{array}$ & $\begin{array}{c}\text { The } \\
\text { Substitution } \\
\text { Effect }\end{array}$ & $\begin{array}{c}\text { The Cost } \\
\text { of Capital } \\
\text { Effect }\end{array}$ & $\begin{array}{c}\text { The } \\
\text { Substitution } \\
\text { Effect }\end{array}$ \\
\hline 0 & NA & NA & 34.71601 & 36.56040 \\
\hline 1 & $231.6583^{\star}$ & $216.8951^{\star}$ & $30.88818^{\star}$ & $33.30039^{\star}$ \\
\hline 2 & 59.28771 & 55.47710 & 32.84988 & 35.46265 \\
\hline 3 & 53.10785 & 64.25926 & 33.50634 & 35.18982 \\
\hline
\end{tabular}

effectiveness of monetary policy as reflected by inflation rate in Indonesia. The findings suggest that a higher financial inclusion rate of the Indonesian population will reduce inflation rate. The findings are in line with Mbutor (2013), Lenka and Bairwa (2016) and Mehrota and Yetman (2014) who show that financial inclusion positively affects the effectiveness of monetary policy as reflected by inflation rate.

The effectiveness of the substitution effect, i.e., people have the options of current or future consumption, causes greater population's response to interest rate changes as

Table 2. The Johansen cointegration test model of the interest rate channel through the cost of capital effect

\begin{tabular}{|c|c|c|c|c|}
\hline \multicolumn{5}{|c|}{ Unrestricted Cointegration Rank Test (Trace) } \\
\hline Null Hypothesis & Eigenvalue & Trace Statistic & 5\% Critical Value & Prob \\
\hline None $^{*}$ & 0.805120 & 156.3768 & 125.6154 & 0.0002 \\
\hline At least $1^{\star}$ & 0.699158 & 99.13886 & 95.75366 & 0.0286 \\
\hline At least 2 & 0.525788 & 57.09791 & 69.81889 & 0.3351 \\
\hline At least 3 & 0.353529 & 30.98439 & 47.85613 & 0.6673 \\
\hline \multicolumn{5}{|c|}{ Unrestricted Cointegration Rank Test (Maximum Eigenvalue) } \\
\hline Null Hypothesis & Eigenvalue & Trace Statistic & 5\% Critical Value & Prob \\
\hline None $^{*}$ & 0.805120 & 57.23794 & 46.23142 & 0.0023 \\
\hline At least $1^{*}$ & 0.699158 & 42.04095 & 40.07757 & 0.0297 \\
\hline At least 2 & 0.525788 & 26.11352 & 33.87687 & 0.3139 \\
\hline At least 3 & 0.353529 & 15.26795 & 27.58434 & 0.7267 \\
\hline
\end{tabular}

Table 3. The Johansen cointegration test model of the interest rate channel through the substitution effect

\begin{tabular}{|c|c|c|c|c|}
\hline \multicolumn{5}{|c|}{ Unrestricted Cointegration Rank Test (Trace) } \\
\hline Null Hypothesis & Eigenvalue & Trace Statistic & 5\% Critical Value & Prob \\
\hline None $^{*}$ & 0.816499 & 184.3378 & 125.6154 & 0.0000 \\
\hline At least $1^{\star}$ & 0.770671 & 124.9941 & 95.75366 & 0.0001 \\
\hline At least $2^{*}$ & 0.572385 & 73.45318 & 69.81889 & 0.0249 \\
\hline At least 3 & 0.489182 & 43.71954 & 47.85613 & 0.1160 \\
\hline \multicolumn{5}{|c|}{ Unrestricted Cointegration Rank Test (Maximum Eigenvalue) } \\
\hline Null Hypothesis & Eigenvalue & Trace Statistic & 5\% Critical Value & Prob \\
\hline \multicolumn{5}{|l|}{ None $^{*}$} \\
\hline \multicolumn{5}{|l|}{ At least $1^{*}$} \\
\hline \multicolumn{5}{|l|}{ At least 2} \\
\hline At least 3 & & & & \\
\hline
\end{tabular}


a monetary policy instrument because higher financial inclusion enables more access to financial institutions. Also, more people can opt for current consumption and less saving or future consumption and more current saving. Such decision is certainly affected by interest rate changes. An overheating economic condition will lead the government to issue a contractive monetary policy and market interest rate will increase. Further, the population responds increased market interest rates by reducing current consumption and increasing their savings. Eventually, consumption and aggregate demand will increase that contains inflation rate increase.

Besides income rate, interest rate also affects consumption. The population with a high financial inclusion rate has options for current consumption and less current savings or future consumption and more current savings. They will respond interest rate changes in the form of the amount of current consumption and savings. Changes in the population's consumption rate will affect aggregate demands and output gaps in the economy that will eventually affect inflation rate. Thus, higher financial inclusion rate will result in effective achievement of inflation target as the final goal of monetary policy.

Similarly, the estimation results show that through the substitution effect, fintech affects inflation rate as the final objective of the monetary policy in Indonesia. The findings are in line with Mylonas et al. (2000), Mishra and Pradhan (2008), Hawkins (2001) and Al-Laham et al. (2009). In the long run, fintech development will affect the effectiveness of monetary policy in Indonesia. Consequently, in the long run, fintech development will change the Indonesian financial structure and in turn, affect household consumption patterns. Eventually, fintech development affects aggregate demand and output gap and the effectiveness of Indonesian monetary policy. However, fintech development only exhibits the long-term impact, and not the short-term one, on inflation rate as the final goal of the Indonesian monetary policy. A likely explanation of these findings is that within the transmission mechanism of monetary policy, fintech affects inflation as the final objective of monetary policy through its impact on the population's financial inclusion rate. In the short run, information is imperfect, and the population has not fully utilized fintech development. Consequently, fintech development will not change the population's consumption pattern and eventually not change inflation rate.

The adjustment coefficient is -1.07 and significant. The results indicate the fast short-term adjustment process towards long-term equilibrium. The past inflation rate is above the equilibrium condition. However, the adjustment process quickly moves towards long-term equilibrium value (Table 5).

Shocks in the impact of the financial inclusion variable on inflation rate are transitory. The results imply that shocks in financial inclusion rate will immediately affect the volatility of inflation rate temporarily (only four periods or one year ahead). Afterward, the impact will return to the equilibrium condition (Figure 1).
Table 5. The estimation results of the inflation model through long-term and short-term substitution effect in Indonesia

\begin{tabular}{|c|c|c|c|}
\hline Variabel & Coefficient & $\begin{array}{l}\text { Standard } \\
\text { Error }\end{array}$ & t-Statistic \\
\hline \multicolumn{4}{|c|}{ Long Term } \\
\hline $\operatorname{PUAB}(-1)$ & 0.245008 & 0.14284 & 1.71523 \\
\hline $\operatorname{DEPRATE}(-1)$ & 0.099881 & 0.08899 & 1.12236 \\
\hline $\operatorname{FINT}(-1)$ & 1.022399 & 0.35415 & 2.88695 \\
\hline $\mathrm{FI}(-1)$ & -26.59151 & 4.37770 & -6.07431 \\
\hline CONS(-1) & 9.79E-06 & $1.5 \mathrm{E}-06$ & 6.44633 \\
\hline OUTGAP(-1) & -0.020194 & 0.00298 & -6.77540 \\
\hline \multicolumn{4}{|c|}{ Short Term } \\
\hline CointEq1 & -1.075939 & 0.27500 & -3.91243 \\
\hline $\mathrm{D}(\operatorname{INF}(-1))$ & 0.046823 & 0.19582 & 0.23912 \\
\hline $\mathrm{D}(\operatorname{PUAB}(-1))$ & 0.557345 & 0.27000 & 2.06426 \\
\hline $\mathrm{D}(\mathrm{DEPRATE}(-1))$ & -0.515915 & 0.22640 & -2.27877 \\
\hline $\mathrm{D}(\mathrm{FINT}(-1))$ & 1.671297 & 1.16401 & 1.43581 \\
\hline $\mathrm{D}(\mathrm{FI}(-1))$ & -16.16019 & 7.22054 & -2.23809 \\
\hline $\mathrm{D}(\mathrm{CONS}(-1))$ & $5.50 \mathrm{E}-06$ & $2.4 \mathrm{E}-06$ & 2.32309 \\
\hline D(OUTGAP $(-1))$ & -0.010441 & 0.00862 & -1.21091 \\
\hline \multicolumn{4}{|c|}{$\mathrm{R}^{2}=0.587101$, Adjusted $\mathrm{R}^{2}=0.460055$, Fstatistic $=4.621175$} \\
\hline
\end{tabular}

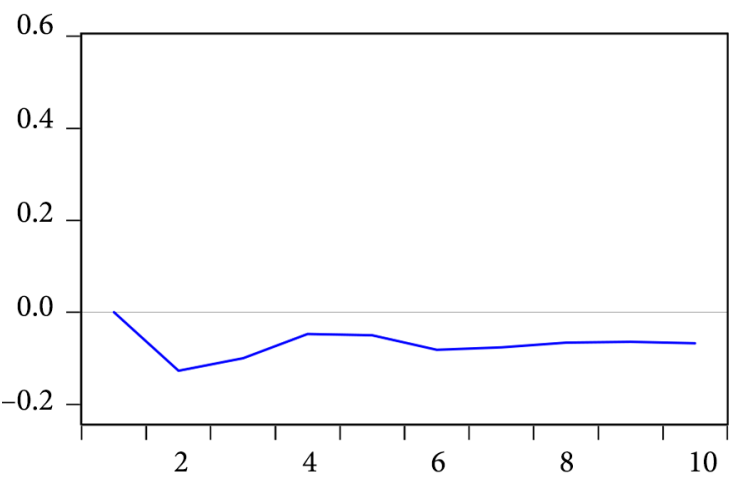

Figure 1. The response of inflation rate on shocks in the financial inclusion variable through the substitution effect

Figure 1 above demonstrates the negative response of inflation as the consequence of shocks in the financial inclusion variable. The findings are in line with Mbutor (2013) who documents that financial inclusion rate positively affects the effectiveness of monetary policy. In particular, Mbutor (2013) uses inflation as the proxy of the effectiveness of monetary policy. The results indicate that a shock in the form of increased financial inclusion rate will be responded by decreased inflation rate until four quarters ahead. In this respect, higher financial inclusion will arguably increase access to financial institutions, especially banks. Also, people will have more saving accounts in banks that reduce outstanding money in the population. Eventually, outstanding money will reduce inflation rate in an economy.

Similarly, shocks in the effect of fintech variable on inflation rate as the ultimate goal of the Indonesian 


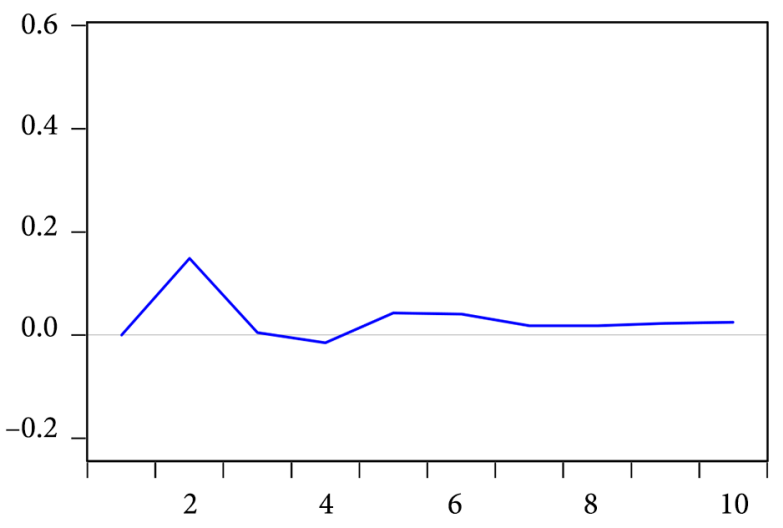

Figure 2. The response of inflation rate on shocks in the Fintech variable through the substitution effect

monetary policy are also relatively short-lived (until four periods ahead), and afterward, the effect will return to the equilibrium condition (Figure 2).

Figure 2 suggests that shocks in the fintech variable will be positively responded by inflation rate. Thus, shocks in the form of fintech development will increase inflation rate probably because fintech development enables the population to engage in more transactions that, in turn, increase the number of transactions. For example, the rapid development of electronic money that facilitates individuals in making transactions and also offers various advantages, such as promotion programs and discounts. These offers surely attract the population to rely more on electronic money than conventional ones in making transactions. In particular, the transaction volume that used electronic money in 2018 is $2,922,698,905$ transactions, a 210 percent increase from 2017 that was only 943,319,333.

Increased transactions will arguably increase households' consumption components in the aggregate demands that eventually will increase inflation rate. However, the impact will last relatively shortly, i.e., four periods ahead, because fintech development will eventually increase outputs in the economy. Thus, increased aggregate demand at the beginning of the fintech development era will be followed by increased outputs in the economy in four

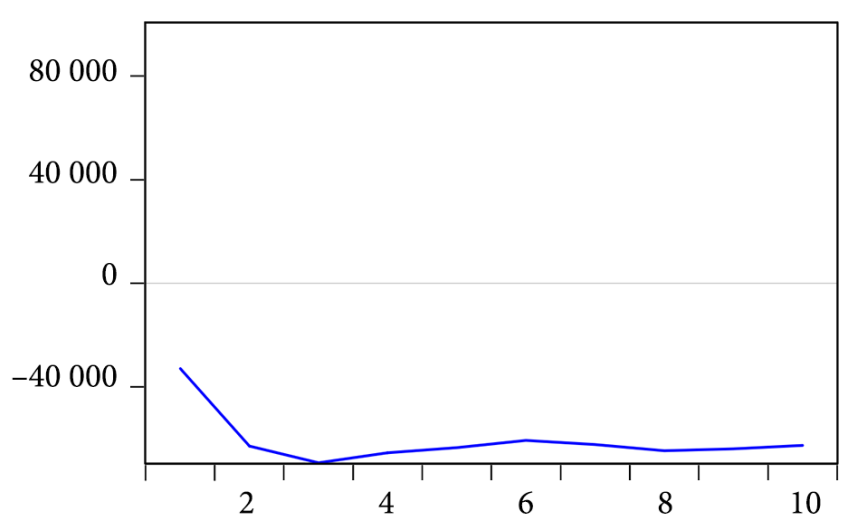

Figure 3. Consumption level's response to shocks in the inter-bank money market interest rate variable with the substitution effect

periods ahead. Increased outputs will eventually mitigate inflation due to increased transactions. Consequently, in the fifth period, inflation rate will be stable again.

The transmission mechanism of monetary policy through the interest rate channel likely affects aggregate demands through changes in interest rate. The effectiveness of monetary policies in affecting the real sector depends on the impact of changes in interest rate as a response to monetary policies of the Central Bank on consumption and investment decisions. With the substitution effect within the framework of the transmission mechanism of monetary policy, shocks in the inter-bank money market interest rate provide fast and significant responses on the volatility of public consumption rate. However, the responses are only temporary (two periods or six months ahead (Figure 3 ). Thus, the public will directly respond to the monetary policies of the Central Bank through changes in interest rate will be responded by the public with their consumption decisions.

Figure 3 above displays that consumption responds negatively to shocks in interest rates. The findings imply that the population will respond to increased interest rates by reducing their consumption level. Higher interest rates will motivate households to add their savings relative to consumption. Besides, higher interest rates also encourage

Table 6. The variance decomposition of consumption

\begin{tabular}{|c|c|c|c|c|c|c|c|c|}
\hline Periode & S.E. & INF & PUAB & DEPRATE & FINT & FI & CONS & OUTGAP \\
\hline 1 & 112925.4 & 3.836796 & 8.494149 & $3.55 \mathrm{E}-07$ & 1.869777 & 78.93696 & 6.862316 & 0.00000 \\
\hline 2 & 167257.6 & 8.6214 & 18.0065 & 1.240152 & 1.283426 & 61.75593 & 9.083636 & 0.008956 \\
\hline 3 & 204764.4 & 6.870342 & 23.43981 & 1.678296 & 1.806645 & 58.19521 & 7.592852 & 0.416843 \\
\hline 4 & 234927.1 & 7.119354 & 25.54572 & 1.558941 & 1.843708 & 57.20135 & 6.367169 & 0.363767 \\
\hline 5 & 263047.2 & 7.284562 & 26.20822 & 1.86271 & 2.015461 & 56.43848 & 5.899624 & 0.290938 \\
\hline 6 & 287850.2 & 6.924917 & 26.31165 & 1.941119 & 2.152007 & 56.61876 & 5.737846 & 0.313701 \\
\hline 7 & 310504.8 & 6.786194 & 26.63807 & 1.89769 & 2.125728 & 56.58209 & 5.636322 & 0.33391 \\
\hline 8 & 331791.6 & 6.836121 & 27.13047 & 1.914346 & 2.112344 & 56.19442 & 5.494252 & 0.318053 \\
\hline 9 & 351777.8 & 6.817383 & 27.44142 & 1.958471 & 2.152379 & 55.98308 & 5.342719 & 0.304547 \\
\hline 10 & 370632.3 & 6.764782 & 27.57348 & 1.978307 & 2.183001 & 55.9572 & 5.244185 & 0.299045 \\
\hline
\end{tabular}


households to work harder and reduce their leisure time to add their incomes and eventually their savings that will generate more interest income. Thus, higher interest rates motivate households to prefer future consumptions to current consumption. The findings are in line with the intertemporal consumption theory as proposed by Irving Fisher.

Besides, within the transmission mechanism of monetary policy through interest rate channel with the substitution effect, household consumption plays a crucial role. The results of the decomposition variance analysis demonstrate that the financial inclusion level is a variable with the most significant role in Indonesian households' consumption decisions. The market interest rate variable is a variable with the second most significant impact on households' consumption decisions (Table 6).

\subsection{The transmission mechanism of monetary policy through interest rate channel with the cost of capital effect}

Within the transmission mechanism of monetary policy through interest rate channel with the cost of capital effect, the estimation results find that the fintech variable only exhibits a short-term impact on the effectiveness of monetary policy as reflected by inflation rate. In the long run, the fintech variable does not affect the effectiveness of monetary policy in Indonesia. The findings support Fiedler et al. (2017) who observe that fintech does not directly affect monetary policy. Fintech will directly affect monetary policy if the official currencies compete with digital money issued by non-bank sectors. The results indicate that fintech development that offers increasingly varied financing sources has only a short-term impact on investment decisions. In the long run, where business actors have perfect information, investment decisions are mainly affected by other factors such as investment climate and macroeconomic conditions. Besides, more varied financing sources are mainly used for consumptive purposes. Consequently, in the long run, fintech development will not affect the effectiveness of monetary policy as reflected by inflation rate.

The impact of the inter-bank money market interest rate on inflation is significantly positive both in the long run and short run. In this respect, increased interbank money market interest rate increases inflation rate probably because the Indonesian inflation rate is mainly cost-push inflation. Consequently, inter-bank money market interest rate will increase costs of production factors through increased cost of capital. However, in the long run, increased credit interest rates will negatively affect inflation rate, implying that when credit interest rate increases inflation will decline. Within the transmission mechanism of monetary policy through interest rate channel with the cost of capital effect, increased credit interest rate will lead to decreased credit demands and reduce firms' investment expenditures. Consequently, aggregate demand will decrease and eventually inflation rate declines.
Similar to the transmission mechanism of monetary policy through interest rate channel with the substitution effect, the financial inclusion rate with the cost of capital effect negatively affects the effectiveness of monetary policy as reflected by inflation rate both in the short run and long run. Thus, increased financial inclusion rates within the society will affect the effectiveness of the achievement of inflation targets in the Indonesian monetary policy. The results confirm Mbutor (2013) and Mehrota and Yetman (2014) who argue that financial inclusion rate negatively affects inflation rate as the indicator of the effectiveness of monetary policy. Increased financial inclusion motivates more people to respond to changes in interest rates. The responses involve changes in firms' investment decisions and households' consumption on durable goods that eventuall will affect aggregate demands, output gap, and inflation.

The adjustment coefficient value is -1.699535 and significant, indicating that the short-term adjustment process towards the long-term equilibrium took place relatively fast. In this respect, prior-period inflation rates are above the equilibrium condition but quickly adjust to the longterm equilibrium condition (Table 7).

Table 7. The estimation results of the inflation model through long-term and short-term cost of capital effect in Indonesia

\begin{tabular}{|c|c|c|c|}
\hline Variable & Coefficient & $\begin{array}{l}\text { Standard } \\
\text { Error }\end{array}$ & t-Statistic \\
\hline \multicolumn{4}{|c|}{ Long Run } \\
\hline $\operatorname{PUAB}(-1)$ & 0.325518 & 0.13068 & 2.49090 \\
\hline DEPRATE(-1) & -0.407368 & 0.15301 & -2.66242 \\
\hline FINT $(-1)$ & 0.375361 & 0.35829 & 1.04765 \\
\hline $\mathrm{FI}(-1)$ & -7.344066 & 2.88922 & -2.54189 \\
\hline $\operatorname{INV}(-1)$ & $4.74 \mathrm{E}-06$ & $1.5 \mathrm{E}-06$ & 3.102251 \\
\hline OUTGAP(-1) & -0.016021 & 0.00240 & -6.66153 \\
\hline \multicolumn{4}{|c|}{ Short Run } \\
\hline CointEq1 & -1.699535 & 0.25969 & -6.54445 \\
\hline $\mathrm{D}(\operatorname{INF}(-1))$ & 0.316175 & 0.16084 & 1.96574 \\
\hline $\mathrm{D}(\mathrm{PUAB}(-1))$ & 0.662480 & 0.20480 & 3.23475 \\
\hline D(DEPRATE $(-1))$ & 0.121719 & 0.42843 & 0.28411 \\
\hline $\mathrm{D}(\mathrm{FINT}(-1))$ & 2.744090 & 0.85132 & 3.22334 \\
\hline $\mathrm{D}(\mathrm{FI}(-1))$ & -11.87502 & 4.73136 & -2.50986 \\
\hline $\mathrm{D}(\mathrm{INV}(-1))$ & $5.06 \mathrm{E}-06$ & $2.2 \mathrm{E}-06$ & 2.24806 \\
\hline D(OUTGAP $(-1))$ & -0.017032 & 0.00675 & -2.52453 \\
\hline
\end{tabular}

Analyzing the impact of shocks in the fintech and financial inclusion rate variables on inflation rate within the transmission mechanism of monetary policy through interest rate channel with the cost of capital effect, shocks in the fintech and financial inclusion rate variables are permanent (Figure 4 and Figure 5). Thus, shocks in fintech in the form of fintech innovation and development will significantly affect the volatility of inflation rate, and the response is permanent. 


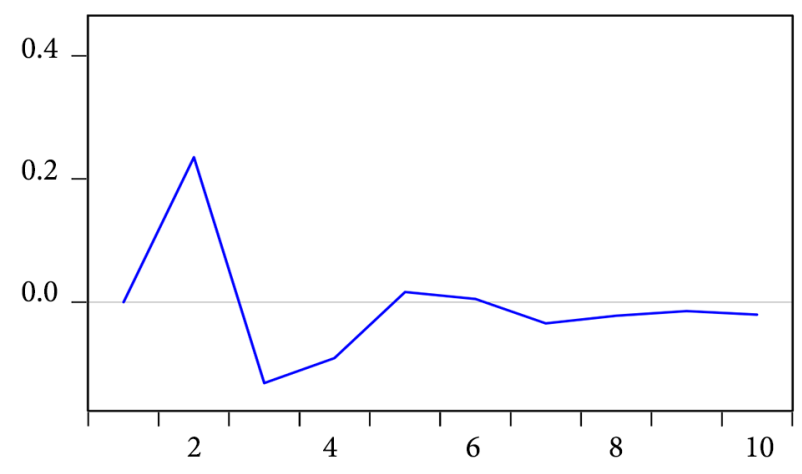

Figure 4. The response of inflation rate to shocks in the Fintech variable with the cost of capital effect

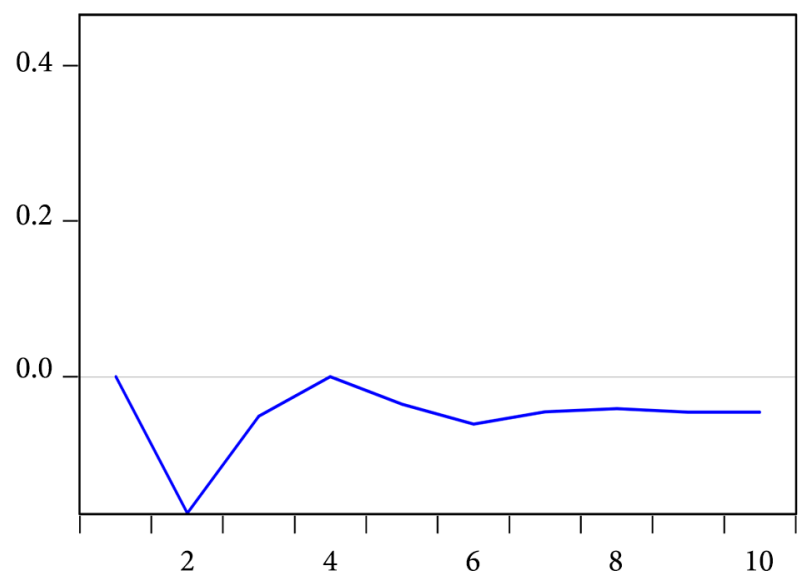

Figure 5. The response of inflation rate on shocks in the financial inclusion rate variable with the cost of capital effect

Figure 4 above suggests that innovative development in fintech leads to relatively steep increases in inflation rate in the early phase. In the following periods, inflation rate declines and continues to fluctuate until ten periods ahead without reaching the equilibrium condition. In this respect, fintech development will likely enable business owners to acquire financing access that increases credit demands from business owners and eventually investments. Specifically, until the end of February 2019, peer-to-peer (P2P) fintech firms managed to allocate $\mathrm{Rp}$ 28 trillion loans.

Increased investment expenditures will increase aggregate demands and eventually inflation rate until two periods (six months) ahead. However, in the following period (the third period), inflation rate declines sharply. Significantly increased inflation rates in the previous periods will reduce purchasing power and consumption that will eventually reduce inflation rate. However, the decline is temporary, and inflation rate will fluctuate again. Until period 10 (2.5 years ahead), shocks in fintech still affect the volatility of inflation rate, and the new equilibrium condition has not been achieved (Figure 4). These findings indicate the permanent effect of shocks in fintech on inflation rate within the framework of the transmission mechanism of monetary policy through interest rate channel with the cost of capital effect.

Different from the effect of shocks in fintech on inflation rate that lasts relatively longer (up to period ten and the new equilibrium condition still not achieved), the effect of shocks in financial inclusion on the volatility of inflation rate lasts relatively shorter (until period 6 or 1.5 years ahead) (Figure 5).

Figure 5 suggests that shocks in the financial inclusion rate variable directly reduces inflation rate because a higher financial inclusion rate indicates that business owners manage to acquire additional financing sources that enable them to increase their outputs. Increased outputs in the economy will reduce output gap. Consequently, increased financial inclusion within the framework of the transmission mechanism of monetary policy through the interest rate channel with the cost of capital effect will reduce inflation rate. However, inflation will increase in the following periods (periods 3 and 4 ) because increased financing to increase outputs in the economy will increase investment expenditures and consumption due to increased labor income. Shocks in financial inclusion rate will affect the volatility of inflation rate until six periods ahead, and in period seven inflation rate will return to the new equilibrium condition.

Table 8. Variance decomposition of investment rate

\begin{tabular}{|c|c|c|c|c|c|c|c|c|}
\hline Periode & S.E. & INF & PUAB & LOAN & FINT & FI & INV & OUTGAP \\
\hline 1 & 79323.72 & 15.75592 & 2.93953 & 15.50741 & 0.405373 & 51.83616 & 13.55562 & 0.00000 \\
\hline 2 & 116919.6 & 18.23458 & 10.79152 & 15.25946 & 0.304062 & 41.52611 & 13.88396 & 0.000307 \\
\hline 3 & 144412.6 & 16.20352 & 14.89426 & 15.03607 & 0.85604 & 40.13865 & 12.77466 & 0.08777 \\
\hline 4 & 166371.3 & 16.19498 & 15.93878 & 15.48055 & 0.806296 & 39.7001 & 11.73192 & 0.147366 \\
\hline 5 & 186424.2 & 16.22088 & 16.22604 & 15.88898 & 0.920572 & 39.41984 & 11.20112 & 0.122565 \\
\hline 6 & 201161.9 & 15.98876 & 16.26037 & 16.20007 & 1.05189 & 39.56362 & 10.81153 & 0.123764 \\
\hline 7 & 220758 & 15.79648 & 16.12675 & 16.56389 & 1.070955 & 39.71607 & 10.58694 & 0.138915 \\
\hline 8 & 235927.1 & 15.7411 & 15.97042 & 16.89828 & 1.065394 & 39.71202 & 10.46999 & 0.142799 \\
\hline 9 & 250250.4 & 15.68447 & 15.863 & 17.15042 & 1.080117 & 39.70521 & 10.37359 & 0.143202 \\
\hline 10 & 263775.9 & 15.61923 & 15.76891 & 17.3555 & 1.093463 & 39.73342 & 10.28333 & 0.146144 \\
\hline
\end{tabular}


Within the system of the transmission mechanism of monetary policy through the interest rate channel with the cost of capital effect, firms' expenditures or investments play a crucial role. Thus, it is necessary to determine the extent of the role of financial inclusion rate and fintech in investment decisions to analyze the impact of both variables on inflation as the ultimate goal of monetary policies.

Table 8 above suggests that the results of the variance decomposition analysis indicate that the financial inclusion rate is a variable that has the most significant impact on investment level in Indonesia. Next, the credit interest rate and inflation rate variables are the variables with the second most significant impact on investment expenditures in Indonesia. The findings imply that not only credit interest rate and macroeconomic condition as reflected by inflation rate that affect firms' investment expenditures but also access to banks that has the most significant role in investment expenditures.

\section{Conclusions}

Within the framework of the transmission mechanism of monetary policy through interest rate channel with both the cost of capital effect and the substitution effect, the financial inclusion rate plays a crucial role in achieving inflation target as an indicator of the effectiveness of monetary policy in Indonesia. This conclusion is empirically supported by our results that demonstrate that financial inclusion rate is the main variable that has a significant impact on households' consumption behavior and firms' investment behavior. In this respect, both consumption and investment are main variables in the transmission mechanism of monetary policy through the interest rate channel that will eventually affect inflation rate.

On the other hand, although not the main variable in forming consumption and investment levels, fintech development is a key variable in the transmission mechanism of monetary policy through the interest rate channel. However, fintech development affects the effectiveness of monetary policy as reflected by inflation rate in Indonesia. Through the cost of capital effect within the framework of the transmission mechanism of monetary policy through interest rate channel, inflation rates' responses to shocks in financial inclusion rate and fintech development are permanent.

Theoretically, the findings imply that the financial inclusion rate and fintech are important in analyzing the framework of the transmission mechanism of monetary policy through interest rate channel to achieve the effectiveness of monetary policy because of their significant influences on households and firms' consumption and investment decisions.

In general, this study suggests that financial inclusion and fintech affect the effectiveness of the Indonesian monetary policy. The findings imply that financial inclusion affects inflation rate that policies should be well-formulated and well-optimized to enhance financial inclusion to stabilize prices. Besides, the achievement of inflation target within the monetary framework is heavily affected by shocks in fintech innovation that the government or central bank regulate fintech effectively in the Indonesian economy.

\section{Acknowledgements}

We would like to thank Bank Indonesia, the Indonesia's Central Banking for providing the secondary data for this data analysis.

\section{Funding}

This research received no specific grant from any funding agency in the public, commercial, or non profit sectors.

\section{Author contributions}

Birgitta Dian Saraswati conceived the study and was responsible for the design, data collection and development of the data analysis. Ghozali Maski, David Kaluge and Rachmad Kresna Sakti were responsible for data interpretation and discussion. Birgitta Dian Saraswati wrote the first draft of the article.

\section{Disclosure statement}

Authors declare that there is no conflict of interest.

\section{References}

Al-Laham, M., Al-Tarawneh, H., \& Abdallat, N. (2009). Development of electronic money and its impact on the Central Bank role and monetary policy. Issues in Informing Science \& Information Technology, 6, 339-349. https://doi.org/10.28945/3328

Amatus, H., \& Alireza, N. (2015). Financial inclusion and financial stability in Sub-Saharan Africa(Ssa). The International Journal of Science, 36(1). https://doi.org/10.1097/ACM.0b013e3182264a25

Ascari, G., Colciago, A., \& Rossi, L. (2011). Limited asset market participation: does it really matter for monetary policy? SSRN. https://doi.org/10.2139/ssrn.1948412

Alexander, K. (2017, July). The role of Finthech and digital financial services. UNCTAD multi-year expert meeting on trade, services and development financial inclusion, 18-20.

Bank Indonesia. (2014). Booklet Keuangan Inklusif. https://www. bi.go.id/id/perbankan/keuanganinklusif/edukasi/Pages/Booklet-Keuangan-Inklusif.aspx

Bank Indonesia. (2018). Statistik Ekonomi dan Keuangan Indonesia. www.bi.go.id

Dabla-Norris, E., Ji, Y., Townsend, R., \& Unsal, D. F. (2015). Distinguishing constraints on financial inclusion and their impact on GDP, TFP, and Inequality, 1-63. NBER working paper series. https://doi.org/10.3386/w20821

Dienillah, Azka, A., \& Anggraeni, L. (2016). Dampak inklusi keuangan terhadap stabilitas sistem keuangan di Asia. Buletin Ekonomi Moneter Dan Perbankan, 18(4), 409-430. http://digilib.unila.ac.id/54922/3/SKRIPSI\%20TANPA\%20 BAB\%20PEMBAHASAN.pdf 
Dupas, S., Keats, A., \& Robinson, P. G. (2013). Challenges in banking the rural poor. Challenges in Banking the Rural Poor, 117(December).

Evans, O. (2016). The effectiveness of monetary policy in Africa: modeling the impact of financial inclusion. According to CGAP 20(3), 327-337. https://ier.ut.ac.ir/article_58961_7b8e 37e5e5fb73a949f9048b0a04650c.pdf

Fiedler, S., Gern, K. J., Kooths, S., \& Stolzenbur, U. (2017). Financial innovation and monetary policy: challenges and prospects. IP/A/ECON/. http://www.europarl.europa.eu/RegData/ etudes/IDAN/2017/602045/IPOL_IDA(2017)602045_EN.pdf

Galí, D., Salido, D. L., \& Valles, J. (2004). Rule of thumb consumers and the design of interest rate rule, 14-15. http://www.crei. cat/wp-content/uploads/users/pages/glv04jmcb.pdf

Greene, W. H. (2002). Econometric analysis (5th ed.). New York. Prentice Hall.

Hannig, A., \& Jansen, S. (2010). Financial inclusion and financial stability: current policy issues. SSRN. https://doi.org/10.2139/ssrn.1729122

Hawkins, J. (2001). Electronic finance and monetary policy. BIS Papers, (7), 98-105. https://www.bis.org/publ/bppdf/bispap07k.pdf

International Monetary Fund IMF. (2018). International financial stastistic. www.imf.org

Julie, O. (2013). The relationship between financial inclusion and GDP growth in Kenya. Research Project Submitted in Partial Fulfillment of the Requirements for the Award of the Degree of Master of Business Administration of the University of Nairobi. http://erepository.uonbi.ac.ke/bitstream/handle/11295/58543/Oruo_Financial\%20Inclusion\%20and\%20 GDPGrowth.pdf? sequence=3

Khan, H. R. (2011). Financial inclusion and financial stability: are they two sides of the same coin? RBI Monthly Bulletin (March), 553-563. https://doi.org/10.1148/radiol.14132404

Kontan. (2018). Fintech Payment masih Mendominasi di 2018. Kontan online 21 Desember 2017. https://keuangan.kontan. co.id/news/fintech-payment-masih-mendominasi-di-2018

Lenka, S. K., \& Bairwa, A. (2016). Does financial inclusion affect monetary policy in SAARC countries? Cogent Economics and Finance, 4(1), 1-8. https://doi.org/10.1080/23322039.2015.1127011

Lapukeni, A. F. (2015). The impact of financial inclusion on monetary policy effectiveness: the case of Malawi. International Journal of Monetary Economics and Finance, 8(4), 360. https://doi.org/10.1504/ijmef.2015.073229

Mbutor, O. (2013). The impact of financial inclusion on monetary policy in Nigeria. Journal of Economics and International Finance, 5(8), 318-326. http://www.academicjournals.org/ app/webroot/article/article1383044040_Mbutor\%20and\%20 Uba.pdf
Mehrotra, A., \& Yetman, J. (2014). Financial inclusion and optimal monetary policy. BIS Working Papers, 476(476), 1-30. https://pdfs.semanticscholar.org/0917/e6af7aeab1bca424bc44b71028d319f384f5.pdf

Mishra, P. K., \& Pradhan, B. B. (2008). Financial innovation and effectiveness of monetary policy. SSRN. https://doi.org/10.2139/ssrn.1262657

Mylonas, P., Schich, S., \& Wehinger, G. (2000). A changing financial environment and the implications for monetary policy, (January). https://pdfs.semanticscholar.org/812d/71e2b8503d 45c4d60261df2d0cd9d74fc63b.pdf

Nakaso, H. (2016). FinTech - its impacts on finance, economies and central banking. FinTech and the Future of Money, (November), 1-7.

Oji, C. K. (2015). Promoting financial inclusion for inclusive growth in Africa. South African Institute of International Affairs. Occasional Paper 210.

Onaolapo, A. R. (2015). Effect of financial inclusion on the economic growth of Nigeria (1982-2012). International Journal of Business and Management Review, 3(8), 11-28.

Pfaff, B. (2008). VAR, SVAR and SVEC models: implementation within R package vars. JSS Journal of Statistical Software, 27(4). http://www.jstatsoft.org/

Sahay, R., Cihak, M., N’Diaye, P., Barajas, A., Mitra, S., Kyobe, A., \& Yousefi, R. (2015). Financial Inclusion: can it meet multiple macroeconomic goals? Staff Discussion Notes, 15(17), 1. https://doi.org/10.5089/9781513585154.006

Sarma, M. (2012). Index of financial inclusion - a measure of financial sector inclusiveness. Working Paper No. 07. https:// finance-and-trade.htw-berlin.de/fileadmin/HTW/Forschung/ Money_Finance_Trade_Development/working_paper_series/ wp_07_2012_Sarma_Index-of-Financial-Inclusion.pdf

Sicilia, J. (2017). Fintech Trends in Emerging ASEAN, (June). https://www.bbvaresearch.com/wp-content/uploads/2017/07/ June-2017-ASEAN-Fintech-Trends1.pdf

Salomon, F., \& Klaus-Jürgen, G. S. (2017). Financial innovation and monetary policy: challenges and prospects. Policy department a: economic and scientific policy.

http://www.europarl.europa.eu/RegData/etudes/IDAN/2017/ 602045/IPOL_IDA(2017)602045_EN.pdf

Svetlana, S., \& Irina, K. M. (2017). Fintech as financial innovation - the possibilities and problems of implementation. European Research Studies Journal, XX(3), 1. https://www.ersj.eu/dmdocuments/2017-xx-3-a-66.pdf

Worldbank. (2014). Global Findex Database. http://databank. worldbank.org/Data/Views/reports/tableview.aspx

Zulfiqar, K., Chaudhary, M. A., \& Aslam, A. 2016. Financial inclusion and its implications for inclusive growth in Pakistan. Pakistan Economic and Social Review, 54(2), 297-325. https://doi.org/10.3402/ejpt.v7.29303 